\title{
Pemanfaatan Energi Pakan pada Sapi Peranakan Ongole dan Sapi Peranakan Ongole x Limousin Jantan Muda yang Diberi Rumput Gajah dan Konsentrat
}

\author{
E. Rianto, M. Y. Effendi dan A. Purnomoadi \\ Fakultas Peternakan Universitas Diponegoro, Semarang
}

\begin{abstract}
ABSTRAK
Penelitian bertujuan untuk mengkaji efisiensi pemanfaatan energi pakan pada sapi Peranakan Ongole (PO) dan sapi PO x Limousin (POL) jantan muda yang dipelihara secara intensif. Penelitian menggunakan 4 ekor sapi PO dan 4 ekor sapi POL dengan umur rata-rata 6 bulan. Bobot badan awal rata-rata sapi PO 78 $\pm 4,69 \mathrm{~kg}$, sapi POL 91,25 $\pm 12,62 \mathrm{~kg}$. Penelitian menggunakan rancangan "Independent Sample Comparison”. Parameter yang diamati meliputi jumlah energi yang dikonsumsi, energi termetabolis, pertambahan bobot badan dan konversi energi. Konsumsi BK sapi PO (26,87 g/kg BB) lebih rendah daripada konsumsi BK sapi POL (33,05 g/kg BB); sehingga konsumsi energi pasa sapi $\mathrm{PO}(0,43 \mathrm{MJ} / \mathrm{kg} \mathrm{BB} / \mathrm{hari})$ juga lebih rendah $(\mathrm{P}<0,05)$ dibanding pada sapi POL $(0,55 \mathrm{MJ} / \mathrm{kg} \mathrm{BB} / \mathrm{hari})$. Tidak terdapat perbedaan yang nyata $(\mathrm{P}>0,05)$ antara kedua bangsa terbut dalam parameter lain yang diamati. Kecernaan energi pakan sapi PO dan POL masingmasing adalah 52,60 dan 52,20\%. Metabolisabilitas energi untuk sapi PO dan POL masing-masing adalah 44,30 dan 42,90\%. Rata-rata pertambahan bobot badan harian untuk sapi PO dan POL masing-masing adalah 0,325 dan 0,412 kg/hari. Konversi energi untuk sapi PO dan POL masingmasing adalah 46,44 dan 55,90 MJ/kg BB. Disimpulkan bahwa sapi PO dan POL jantan muda yang dipelihara secara intensif memiliki kemampuan yang sama dalam pemanfaatan energi pakan.
\end{abstract}

Kata kunci : Sapi, bangsa, metabolisme energi.

\section{Dietary Energy Utilization in Ongole Grade and Ongole Grade x Limousin Young Bulls Fed Napier Grass and Concentrate}

\begin{abstract}
An experiment was carried out to investigate the efficiency of dietary energy utilisation in Ongole Grade (OG) and OG x Limousin (OGL) young bulls under intensive feeding regime. This experiment used 4 OG and 4 OGL young bulls (about 6 months old). The initial body weight of OG was $78 \pm 4.69 \mathrm{~kg}$, and that of OGL was $91.25 \pm 12.62 \mathrm{~kg}$. This experiment used "Independent Sample Comparison" method. Parameters observed were energy intake, energy digestibility, energy metabolisability, live weight gain and energy conversion. The results showed that dry matter (DM) intake of OG PO (26.87 $\mathrm{g} / \mathrm{kg} \mathrm{BB})$ was lower $(P<0.05)$ than that of OGL $(33.05 \mathrm{~g} / \mathrm{kg} \mathrm{BB} / \mathrm{d})$; so that energy intake of $O G(0.43 \mathrm{MJ} / \mathrm{kg} B B / \mathrm{d})$ was also lower $(P<0,05)$ than that of OGL $(0.55 \mathrm{MJ} / \mathrm{kg}$ $B B / d)$.However, were not significant difference $(P>0.05)$ between the two breeds in all other parameters observed. Dietary energy digestibility's in OG and OGL were 52.60 and 52.20\%, respectively. Energy metabolisability's in OG and OGL were 44.30 and $42.90 \%$, respectively. Live weight gain of were 0.325 and $0.412 \mathrm{~kg} / \mathrm{d}$ in $O G$ and OGL, respectively Energy conversions in $O G$ and OGL were 46.44 and $55.90 \mathrm{MJ}$ per kilogram live weight gain. It was concluded that OG and OGL young bulls under intensive feeding regime had similar performance in energy utilisation.
\end{abstract}

Key words: Bulls, breed, energy metabolism 


\section{PENDAHULUAN}

Bangsa sapi yang paling banyak dipelihara di P. Jawa adalah Sapi Peranakan Ongole (PO). Sapi ini merupakan hasil persilangan antara sapi Ongole jantan dan sapi lokal betina. Sapi PO banyak dipelihara oleh petani kecil di pedesaan dengan manajemen pemeliharaan sederhana dan dengan jenis pakan yang rendah kualitasnya, sehingga tidak mengherankan kalau produktivitasnya rendah. Sekitar tahun 1970 sapi dari benua Eropa banyak diimpor dan dibudidayakan di Indonesia. Salah satu bangsa sapi tersebut adalah sapi Limousin. Sapi Limousin di JawaTengah disilangkan dengan sapi PO, dan menghasilkan sapi Peranakan Ongole $\mathrm{X}$ Limousin (POL). Tujuan persilangan ini adalah untuk meningkatkan bobot lahir dan laju pertambahan bobot badan.

Produktivitas ternak dapat diketahui dari efisiensi penggunaan pakan yang dikonsumsi. Pakan yang dikonsumsi akan pencernaan dalam saluran pencernaan. Pada proses ini sebagian energi akan terbuang dalam bentuk gas methana dan energi dalam feses, dan sebagian yang lain diserap oleh tubuh dan digunakan dalam proses metabolisme. Sebagian dari energi yang terserap terbuang melalui urin dan sebagian yang lain disimpan dalam tubuh atau terpakai sebagai panas tubuh. Energi yang tersimpan digunakan untuk mencukupi hidup pokok, dan selebihnya ditimbun sebagai daging atau lemak.

Tujuan dari penelitian ini adalah mengetahui metabolisme energi sapi PO dan sapi POL yang dipelihara secara intensif. Hasil penelitian ini diharapkan dapat memberikan informasi tentang kemampuan sapi PO dan POL dalam memanfaatkan energi ransum.

\section{MATERI DAN METODE}

Materi yang digunakan dalam penelitian ini berupa 4 ekor sapi PO dan 4 ekor sapi POL dengan umur rata-rata 6 bulan. Bobot badan awal rata-rata sapi $\mathrm{PO}$ adalah $78 \pm 4,69 \mathrm{~kg}$ (CV=6,01\% dan sapi POL 91,25 $\pm 12,62 \mathrm{~kg}$ $(\mathrm{CV}=13,80 \%)$. Sapi-sapi tersebut ditempatkan secara acak di dalam kandang petak yang dilengkapi dengan tempat pakan dan minum.

Bahan pakan yang digunakan dalam penelitian ini adalah rumput gajah yang dilayukan dan konsentrat. Rumput gajah diberikan secara ad libitum, sedangkan konsentrat diberikan sebanyak 1,5\% dari bobot badan. Komposisi nutrisi pakan yang digunakan tercantum pada Tabel 1.

\section{Rancangan Percobaan}

Rancangan percobaan yang digunakan adalah metode "Independent Sample Comparison” (Steel dan Torrie, 1984), yaitu membandingkan 2 kelompok materi penelitian yang berbeda. Pada penelitian ini ada 2 materi yang dibandingkan, yaitu sapi PO (kelompok 1) dan sapi POL (kelompok 2). Kedua bangsa tersebut masing-masing berjumlah 4 ekor.

\section{Prosedur Penelitian}

Ternak percobaan diberi hijauan dan konsentrat berdasarkan bobot badan masingmasing ternak. Konsentrat diberikan dua kali sehari, pada pukul 07.00 dan 15.00 WIB, sedangkan hijauan diberikan 2 jam setelah pemberian konsentrat. Air minum diberikan secara ad libitum. Penimbangan pakan yang diberikan dan yang tersisa dilakukan setiap pagi hari. Penimbangan ternak dilakukan setiap minggu 1 sekali pada pagi hari sebelum ternak diberi pakan.

Koleksi total feses dan urin yang dikeluarkan oleh ternak dilakukan 4 hari berturut-turut pada awal minggu periode perlakuan. Koleksi total dilakukan mulai pukul 07.00 WIB dan berakhir pada jam yang sama di hari berikutnya. Hasil penampungan feses dan urin pada pagi harinya ditimbang dan kemudian diambil sampel. Pengambilan sampel pada feses dan urin dilakukan setelah pengadukan hingga merata. 
Tabel 1. Komposisi Nutrisi Bahan Pakan yang Digunakan

\begin{tabular}{lcccccc}
\hline \hline Bahan Pakan & BK & PK & Abu & SK & LK & BETN \\
\hline Rumput Gajah & 61,59 & 10,15 & 9,08 & 23,51 & 1,04 & 56,22 \\
Konsentrat & 90,10 & 14,15 & 15,95 & 28,59 & 5,04 & 36,26 \\
\hline
\end{tabular}

Pengambilan sampel feses pada berikutnya disesuaikan proporsinya dengan pengambilan pada hari pertama. Hasil total koleksi feses selama 4 hari kemudian dikeringkan. Feses yang kering ditumbuk dan dicampur hingga homogen, kemudian diambil subsampel untuk dianalisis. Sampel urin diambil secara proporsional setiap hari dengan penentuan nilai proporsinya didapat dari pengambilan sampel hari pertama. Sampel diambil kurang lebih 250 g. Pengambilan sampel urin pada hari berikutnya disesuaikan proporsinya dengan pengambilan pada hari pertama. Hasil total koleksi urin selama 4 hari dicampur dan diaduk hingga homogen, kemudian diambil subsampel untuk dianalisis. Analisis kandungan energi pakan, feses dan urin dilakukan dengan bom kalorimeter.

\section{Parameter Penelitian}

Parameter yang diamati dalam penelitian ini adalah jumlah BK dan energi yang dikonsumsi, energi yang terkandung dalam feses, energi yang terkandung dalam urin, energi dalam $\mathrm{CH} 4$, pertambahan bobot badan dan konversi energi pakan. Pakan yang dikonsumsi diukur dengan selisih pakan yang diberikan dikurangi dengan sisa pakan. Jumlah energi yang dikonsumsi dari rumput gajah dan konsentrat dihitung dengan selisih dari jumlah pakan yang diberikan dan sisa pakan.

Kandungan energi yang keluar dari feses dan urin diambil sampel kemudian dianalisis, energi yang keluar berupa gas methana diukur dengan menggunakan "Face Mask Method" (cerobong muka) yang dihubungkan dengan "CH4 analyser" (Alat pengukur CH4 dengan merk "Horiba Ltd", Jepang). Pengukuran dilakukan selama 2 hari, dengan lama pengukuran 10 menit tiap sapi dengan interval selama 3 jam. Data 2 hari tersebut dirata-rata menjadi data per hari.

Metabolisabilitas energi dihitung dengan cara pengurangan dari jumlah energi yang terkandung dalam pakan yang dikonsumsi dikurangi dengan energi dalam feses, energi dalam urin dan energi methana. Konversi energi terkonsumsi, tercerna serta terdoposisi dihitung dari jumlah konsumsi energi yang terkonsumsi, tercerna dan termetabolisa dibagi dengan pertambahan bobot badan. Data yang diperoleh dari penelitian akan diuji dengan $t$ student (uji-t).

\section{HASIL DAN PEMBAHASAN}

\section{Konsumsi dan Kecernaan Pakan}

Hasil rata-rata konsumsi bahan kering (BK), pengeluaran BK feses, dan BK tercerna ditampilkan pada Tabel 2. Konsumsi BK total rata-rata harian pada kedua bangsa terdapat perbedaan yang nyata $(\mathrm{P}<0,05)$. Konsumsi $\mathrm{BK}$ hijauan, BK konsentrat tidak berbeda nyata $(\mathrm{P}>0,05)$. Sumbangan BK hijauan terhadap konsumsi BK total pada sapi PO dan POL masing-masing adalah sebesar 57,02\% dan 47,80\%. Sumbangan BK konsentrat terhadap konsumsi BK total sapi PO adalah sebesar 42,98\%, dan sapi POL adalah sebesar 52,2\% dari total konsumsi BK.

Adanya perbedaan antara kedua bangsa dalam konsumsi BK menunjukkan bahwa kedua bangsa tersebut memiliki kemampuan yang berbeda dalam mengkonsumsi pakan. Dijelaskan oleh Crampton dan Harris (1969) dan Frandson (1994) bahwa pada masingmasing bangsa ternak punya kemampuan yang berbeda dalam mengkonsumsi bahan pakan. 
Perbedaan konsumsi BK total pada kedua bangsa tersebut sebagian besar disebabkan oleh perbedaan dalam konsumsi BK konsentrat, dimana konsumsi konsentrat dari sapi POL yang lebih tinggi dari sapi PO, meskipun secara statistik tidak berbeda nyata (Tabel 2). Hal ini juga dapat dilihat dari kenyataan bahwa sapi POL cenderung mengkonsumsi lebih banyak konsentrat daripada sapi PO, dilihat dari proporsinya terhadap konsumsi BK total.

BK feses antara kedua bangsa sapi berbeda nyata $(\mathrm{P}<0,05)$. Pengeluaran $\mathrm{BK}$ melalui feses sapi PO adalah 12,77 g/kg BB dan pada sapi POL adalah 16,22 g/kg BB. Perbedaan jumlah BK feses yang dikeluarkan ini wajar terjadi, karena konsumsi BK juga berbeda.

Tingkat kecernaan BK pada sapi PO adalah 52,59\% dan pada sapi POL adalah 50,56\% dari total konsumsi. Tingkat kecernaan BK antara kedua bangsa sapi tidak berbeda nyata $(\mathrm{P}>0,05)$. Perbedaan tingkat konsumsi BK pada kedua bangsa tersebut ternyata tidak berpengaruh terhadap kecernaan BK- Tingkat kecernaan pakan antara lain dipengaruhi oleh laju pakan dalam saluran pencernaan (Campbell dan Lasley, 1977; Ranjhan dan Pathak, 1989). Lebih lanjut dijelaskan oleh Campbell dan Lasley, (1977) dan Ranjhan dan Pathak (1989) bahwa laju pakan yang cepat dalam saluran pencernaan akan menurunkan daya cerna. Laju pakan dalam saluran pencernaan antara lain dipengaruhi oleh tingkat konsumsi pakan (McDonald et al., 1988). Tidak adanya perbedaan yang nyata antara sapi PO dan sapi POL dalam hal kecernaan BK, menunjukkan bahwa saluran pencernaan pada sapi POL mempunyai kemampuan yang lebih tinggi daripada sapi PO dalam menampung digesta, sehingga meskipun konsumsi BK pada sapi POL lebih tinggi daripada sapi PO, laju pakan dalam saluran pencernaan tidak berbeda.

\section{Metabolisme Energi}

Rata-rata konsumsi energi pakan, pengeluaran energi dalam feses, urin, gas methana, dan energi tercerna serta energi termetabolisa dapat dilihat pada Tabel 3 . Energi termetabolisa yang dimaksud dalam penelitian ini adalah energi yang tersisa dari konsumsi energi pakan setelah dikurangi dengan energi yang keluar melalui feses, urin dan gas methana. Konsumsi energi rata-rata kedua bangsa sapi pada penelitian ini berbeda nyata $(\mathrm{P}<0,05)$; konsumsi energi pada sapi $\mathrm{PO}$ adalah 0,43 MJ/kg BB/hari dan pada sapi POL adalah 0,55 MJ/kg BB/hari. Konsumsi energi sapi POL lebih tinggi daripada sapi PO. Hal ini diduga karena faktor bangsa, dimana tiap bangsa ternak mempunyai kecepatan metabolisme yang berbeda (Soeparno, 1998). Perbedaan kecepatan metabolisme sangat berpengaruh terhadap kebutuhan energi, yang secara langsung akan berpengaruh terhadap jumlah energi terkonsumsi (McDonald et al., 1988; Crampton dan Harris,1969).

Terdapat perbedaan nyata $(\mathrm{P}<0,05)$ antara sapi PO dan POL dalam pengeluaran energi melalui feses. Pengeluaran energi feses pada sapi PO adalah $0,20 \mathrm{MJ} / \mathrm{kg} \mathrm{BB} /$ hari atau sebesar 47,30\%, sedangkan pada sapi POL adalah 0,26 MJ/kg BB/hari atau sebesar

Tabel 2. Konsumsi dan Kecernaan Bahan Kering Pakan

\begin{tabular}{lccc}
\hline \hline Parameter & Sapi PO & Sapi POL & Perbedaan \\
\hline Konsumsi BK total (g/kg BB) & 26,87 & 33,05 & $*$ \\
Konsumsi BK Hijauan (g/kg BB) & 15,27 & 15,80 & $\mathrm{~ns}$ \\
Konsumsi BK Konsentrat (g/kg BB) & 11,60 & 17,60 & $\mathrm{~ns}$ \\
Pengeluaran BK Feses (g/kg BB) & 12,77 & 16,22 & $*$ \\
Kecernaan BK (\%) & 52,59 & 50,86 & $\mathrm{~ns}$ \\
\hline
\end{tabular}

Keterangan : BK : Bahan Kering

* : Berbeda nyata $(\mathrm{P}<0,05)$

ns : Tidak berbeda nyata $(\mathrm{P}>0,05)$ 
Tabel 3. Konsumsi, Kecernaan, Metabolisabilitas Energi Pakan, dan Pertambahan Bobot Badan Harian.

\begin{tabular}{lccc}
\hline \hline \multicolumn{1}{c}{ Parameter } & Sapi PO & Sapi POL & Perbedaan \\
\hline Konsumsi Energi (MJ/kg BB/hari) & 0,43 & 0,55 & $*$ \\
Pengeluaran Energi : & & & $*$ \\
$\quad$ Feses (MJ/kg BB/hari) & 0,20 & 0,26 & $\mathrm{~ns}$ \\
$\quad$ Urin (MJ/kg BB/hari) & 0,007 & 0,015 & $\mathrm{~ns}$ \\
$\quad$ Gas Methana (MJ/kg BB/hari) & 0,026 & 0,027 & $\mathrm{~ns}$ \\
Kecernaan Energi (\%) & 52,60 & 52,20 & $\mathrm{~ns}$ \\
Metabolisabilitas Energi (\%) & 44,30 & 42,90 & $\mathrm{~ns}$ \\
PBBH (g/hari) & 325 & 412 & \\
\hline
\end{tabular}

Keterangan : PBBH : Pertambahan Bobot Badan Harian

$$
\begin{aligned}
& * \quad: \text { Berbeda nyata }(\mathrm{P}<0,05) \\
& \mathrm{ns} \quad: \text { Tidak berbeda nyata }(\mathrm{P}>0,05)
\end{aligned}
$$

48,30\% dari total energi terkonsumsi. Pengeluaran energi melalui feses masih dalam kisaran umum sebagaimana yang dinyatakan Bondi (1987), bahwa pengeluaran energi melalui feses berkisar antara 45-50\% dari total konsumsi energi. Data pada Tabel 2 menunjukkan bahwa tingkat kecernaan energi pada sapi PO dan sapi POL pada penelitian ini tidak berbeda nyata $(\mathrm{P}>0,05)$. Hal ini sejalan dengan hasil yang menunjukkan bahwa kecernaan BK pada kedua bangsa sapi tidak berbeda nyata ( $\mathrm{P}>0,05$, Tabel 2 ). Faktor yang mempengaruhi kecernaan antara lain kualitas pakan, jumlah pakan yang dikonsumsi serta kecepatan pakan dalam saluran pencernaan (Ranjhan dan Pathak, 1989), dimana kecernaan energi untuk sapi PO dan POL masing-masing 52,60\% dan 52,20\%. Energi yang terbuang melalui urin untuk sapi PO dan POL masingmasing adalah 0,007 $\mathrm{MJ} / \mathrm{kg} \mathrm{BB} / \mathrm{hari}$ atau sebesar $1,7 \%$ dan $0,015 \mathrm{MJ} / \mathrm{kg}$ BB/hari atau sebesar 2,8\% dari total konsumsi energi. Pengeluaran energi melalui urin dalam penelitian ini hampir sama dengan yang dilaporkan Nonaka et al. (2001), yaitu sebesar 2,9\% pada sapi Friesian Holstein laktasi. Pengeluaran energi tersebut sedikit lebih rendah dari yang dikemukakan Van Soest (1994), bahwa pengeluaran energi melalui urin berkisar antara 3-5\% dari total energi terkonsumsi. Pengeluaran energi melalui urin dipengaruhi oleh metabolisme dalam tubuh ternak (MacRae dan Lobley, 1982). Energi yang terbuang melalui urin tersebut secara statistik tidak berbeda nyata $(\mathrm{P}>0,05)$.

Energi yang keluar dalam bentuk gas methana pada sapi PO dan POL masing-masing adalah 0,026 MJ/kg BB/hari dan 0,027 MJ/kg $\mathrm{BB} /$ hari atau sebesar 6,10 dan $4,80 \%$ dari total energi terkonsumsi. Pengeluaran gas methana pada sapi PO dan POL tidak berbeda nyata $(\mathrm{P}>0,05)$. Jumlah pengeluaran tersebut masih dalam kisaran umum sebagaimana yang dinyatakan Van Soest (1994), bahwa pengeluaran energi melalui gas methana berkisar antara 5-12\%. Persentase pengeluaran yang rendah ini menunjukkan bahwa pakan yang diberikan berkualitas baik.

Faktor-faktor yang mempengaruhi pengeluaran energi melalui gas methana adalah kualitas nutrisi pakan, konsumsi pakan dan kecernaan pakan (Holter dan Young, yang disitasi oleh Kurihara et al., 1997). Dijelaskan oleh Shibata et al. (1993) bahwa jumlah konsumsi pakan yang tinggi cenderung akan meningkatkan pengeluaran gas methana, dan kualitas pakan yang baik akan cenderung menurunkan pengeluaran jumlah gas methana.

Metabolisabilitas energi untuk sapi PO dan POL masing-masing adalah sebesar $44,30 \%$ dan 42,90\% dari total energi terkonsumsi. Metabolisabilitas energi dalam penelitian ini lebih rendah dari yang dilaporkan Nonaka et al. (2001), yaitu 59\% dari jumlah 
Sains Peternakan Vol. 8 (1), Maret 2010: 15-21

ISSN 1693-8828

Tabel 4. Konversi Energi Kasar Terkonsumsi, Konversi Energi Tercerna dan Konversi Energi Termetabolisa.

\begin{tabular}{lccc}
\hline \hline & Sapi PO & Sapi POL & \\
Parameter & ------ & MJ/kg BB & Perbedaan \\
\hline Konversi Energi Kasar Terkonsumsi & 103,40 & 128,10 & $\mathrm{~ns}$ \\
Konversi Energi Tercerna & 54,61 & 64,92 & $\mathrm{~ns}$ \\
Konversi Energi Termetabolisa & 46,44 & 55,90 & $\mathrm{~ns}$ \\
\hline
\end{tabular}

Keterangan : ns : tidak berbeda nyata $(\mathrm{P}>0,05)$

energi terkonsumsi dengan materi sapi Holstein laktasi.

Metabolisabilitas energi dipengaruhi oleh komposisi nutrisi pakan, tingkat kecernaan dan kondisi fisiologis ternak (Boorman, 1980). Energi termetabolisa pada penelitian ini bernilai positif, artinya ada kemampuan untuk meningkatkan pertambahan bobot badan harian ternak (Maynard dan Loosli, 1969).

\section{Konversi Energi}

Konversi energi kasar untuk membentuk $1 \mathrm{~kg}$ bobot badan pada sapi PO dan POL masing-masing adalah sebesar 103,40 dan $128,10 \mathrm{MJ} / \mathrm{kg}$, dari energi yang tercerna untuk sapi PO dan POL masing-masing adalah 54,61 dan 64,92 $\mathrm{MJ} / \mathrm{kg}$ dan dari energi yang termetabolisa adalah sebesar 46,44 dan 55,90 $\mathrm{MJ} / \mathrm{kg}$ (lihat Tabel 4). Konversi energi baik energi bruto, energi tercerna dan energi termetabolisa pada sapi PO dan sapi POL tidak berbeda nyata $(\mathrm{P}>0,05)$. Hal ini mengindikasikan bahwa kebutuhan energi untuk hidup pokok dan pertambahan bobot tubuh pada sapi PO dan sapi POL hampir sama, yang berarti pula bahwa ditinjau dari penggunaan energi pakan, kedua bangsa sapi tersebut mempunyai efisiensi produksi yang hampir sama.

\section{KESIMPULAN DAN SARAN}

\section{Kesimpulan}

Berdasarkan hasil penelitian ini dapat disimpulkan bahwa sapi PO dan POL jantan muda memiliki kemampuan yang tidak berbeda dalam hal pemanfaatan energi pakan.

\section{Saran}

Perbandingan antar bangsa sapi dalam hal kemampuan berproduksi (pertambahan bobot badan) hendaknya dilakukan dengan memperhatikan efisiensi pemanfaatan nutrisi pakan, bukan hanya laju pertambahan bobot badan.

\section{DAFTAR PUSTAKA}

Bondi, A. A. 1987. Animal Nutrition. John Wiley dan Sons, Chichester.

Boorman, K. N. 1980. Dietary constraints on nitrogen retention. Dalam: P. J. Buttery dan D. B. Lindsay (Ed). Protein Deposition in Animals. Butterworths, London. Hal 147-166.

Campbell, J. R. dan J. F. Lasley, 1977. The Science of Animals that Serve Mankind. $2^{\text {nd }}$ Ed. McGraw-Hill, Inc., USA.

Crampton, C.W. dan L. Harris. 1969. Applied Animal Nutrition $2^{\text {nd }}$ Ed. W.H. Freeman and Company, San Francisco.

Frandson, R.D. 1994. Anatomi dan Fisiologi Ternak. Gadjah Mada University Press, Yogyakarta. (Diterjemahkan oleh B. Srigandono dan K . Praseno).

Kurihara, M., M. Shibata, F. Terada, T. Nishida, dan A. Purnomoadi. 1997. Methane production and its dietary manipulation in Ruminants. Dalam: R. Onodera. H. Itabashi. K. Ushida. H. Yano dan Y. Sasaki (Ed). Rumen Microbes and Digestive Physiology in Ruminants. Japan Scientific Societies Press, Tokyo dan S. Karger, A. G, Basel, Switzerland. Hal 199-208.

MacRae, J.C. dan G.E. Lobley. 1982. Control of digestion and metabolism in ruminant. Dalam: L.P. Milligan, W.L. Grovum, A. Dobson (Ed). 
Proceeding of the Sixth International Symposium on Ruminant Physiology. Englewood Cliffs, Hal 367-385.

Maynard, L.A. dan J.K. Loosli, 1969. Animal Nutrition. Tata McGraw-Hill Company Ltd., New Delhi.

McDonald, P., R. A. Edwards dan J. F. P. Greenhalgh. 1988. Animal Nutrition. $4^{\text {nd }}$ Ed. Longman Scientific and Technical, New York.

Nonaka, I, F. Itoh, A. Purnomoadi, K. Higuchi, O. Enishi, F. Terada dan Y. Obara, 2001. Energy metabolism in lactating cows treated with recombinant bovine somatotropin under high environmental temperature. Dalam: A. Chwalibog dan K. Jakobsen. (Ed). Energy Metabolism in Animals. EAAP Publication, Snekkersten, Denmark. Hal 397-400.

Ranjhan, S.K. dan N.N. Pathak. 1989. Management and Feeding of Buffaloes. Vikas Publishing House, Puv, Ltd., New Delhi.
Shibata, M., F. Terada. M. Kurihara. T. Nishida. dan K. Iwasaki. 1993. Methane production and its dietary manipulation in ruminants. Dalam : R. Onodera. H. Itabashi. K. Ushida. H. Yano dan Y. Sasaki. (Ed). Rumen Microbes and Digestive Physiology in Ruminants. Japan Scientific Societies Press, Tokyo dan S. Karger, A. G, Basel, Switzerland. Hal 199-208.

Soeparno, 1998. Ilmu dan Teknologi Daging. Gadjah Mada University Press, Yogyakarta.

Steel, R.G.D. dan J.H. Torrie, 1984. Principles and Procedures of Statistics, Biometrical Approach. $2^{\text {nd }}$ Ed. McGraw-Hill International Book Company, Singapura.

Van Soest, P.J. 1994. Nutritional Ecology of the Ruminant. $\quad 2^{\text {nd }} \quad$ Ed. Comstock Publishing Associates A Division of Cornell University Press, Ithaca and London. 